\title{
PEMODELAN APLIKASI PENDUKUNG KEPUTUSAN MAKANAN PENDAMPING AIR SUSU IBU (MPASI) BERBASIS ANDROID
}

\author{
Rabby Nazli'), Erlinda ${ }^{2}$ \\ ${ }^{1}$ Fakultas Teknik, Universitas Islam Kuantan Singingi, Jl. Gatot Subroto KM.7 Jake teluk Kuantan Riau \\ email: rabbynazli@gmail.com \\ ${ }^{2}$ Fakultas Teknik, Universitas Islam Kuantan Singingi, Jl. Gatot Subroto KM.7 Jake teluk Kuantan Riau \\ email: erlinda120015@gmail.com
}

\begin{abstract}
Complementary foods breast milk (MPASI) is a very important thing for growth and development in a baby, to achieve optimal growth and development process, balanced nutrition is needed, even nowadays babies are often stunted or have malnutrition. Good parents, of course, do not just provide complementary foods to their babies but will pay attention to whether or not the MPASI nutrition is given. By modeling an MPASI guide application, it can help parents determine the right nutrition to give to their babies and parents can make the right decisions and find out the nutritional status of their babies. Modeling this application using Unifield Modeling Language (UML) and implemented into the application using Android Studio. From the resulting application model, it can help and provide references to parents in providing balanced nutrition for their babies.
\end{abstract}

Keywords: Decision Support, MPASI, Nutrition, stunting, Android

\begin{abstract}
Abstrak
Makanan Pendamping Air Susu Ibu (MPASI) merupakan satu hal yang sangat penting untuk tumbuh kembang pada seorang bayi, untuk mencapai proses tumbuh kembang secara optimal maka diperlukan nutrisi yang seimbang bahkan saat ini sering sekali terjadi bayi stunting atau mengalami gizi buruk. Orang tua yang baik tentunya tidak sekedar memberikan MPASI kepada bayinya tetapi akan memperhatikan sudah benar atau belum nutrisi MPASI yang diberikan. Dengan memodelkan sebuah aplikasi panduan MPASI dapat membantu orang tua dalam menentukan nutrisi yang tepat untuk diberikan kepada bayinya dan orang tua bisa mengambil keputusan yang tepat dan mengetahui status gizi pada bayi mereka. Memodelkan Aplikasi ini menggunakan Unifield Modelling Language (UML) dan di implementasikan kedalam Aplikasi menggunakan Android Studio. Dari model Aplikasi yang dihasilkan maka dapat membantu dan memberikan rujukan kepada orang tua dalam memberikan nutrisi yang seimbang untuk bayi mereka.
\end{abstract}

Kata Kunci : Pendukung Keputusan, MPASI, Nutrisi, stunting, Android

\section{PENDAHULUAN}

Stunting merupakan masalah gizi yang menjadi perhatian khusus pemerintah saat ini, hal ini sangat penting karena menyangkut sumber daya manusia dimasa yang akan datang. Untuk pencegahan dalam kasus stunting sendiri tentunya tidak bisa diselesaikan pada sektor kesehatan saja tetapi juga perlu pengetahuan orang tua dalam hal pemberian nutrisi yang optimal dan seimbang untuk tumbuh kembang seorang bayi. Proses pemberian asupan gizi yang optimal ini tentunya harus diberikan sejak dini kepada bayi terutama disaat memberikan makanan pendamping ASI (MPASI). 
Pada usia emas bayi enam sampai dua puluh empat bulan, air susu ibu (ASI) sudah tidak dapat memenuhi asupan kebutuhan nutrisi yang optimal dan seimbang. Oleh karena itu bayi perlu diberikan makanan pendamping ASI (MPASI), yaitu yang mencakup seluruh makanan padat dan cair selain air susu ibu atau susu formula (Agostoni et al. 2008). World Health Organization (WHO) merekomendasikan tiga standar emas yang harus diperhatikan oleh para orangtua dalam pemberian gizi, yaitu Inisiasi Menyusui Dini (IMD), ASI eksklusif (0-6 bulan), dan pemberian MP-ASI (Makanan Pendamping Air Susu Ibu) yang berkualitas dan bergizi (6- 24 bulan) (Indria, 2017).

Didalam hal mengatasi masalah kasus stunting ini penelitian ini bertujuan khusus untuk memberikan pengetahuan, panduan dan media pengambilan keputusan orang tua dalam memberikan MPASI yang memiliki nutrisi yang optimal. Hal ini sangat perlu cepat dilakukan karena kasus stunting di indonesia saat ini memiliki persentasi yang sangat tinggi, berdasarkan data yang dikumpulkan World Health Organization (WHO) Indonesia termasuk negara ketiga dengan prevalensi tertinggi diregional asia tenggara. Rata-rata prevalensi balita stunting di indonesia tahun 2005 - 2017 adalah 36,4\%.

Kabupaten Kuantan Singingi berdasarkan Laporan Provinsi Riau Riskesdas 2018, anak dibawah dua tahun mengalami gizi buruk sebanyak 1,28\%, gizi kurang sebanyak $11,12 \%$ dan gizi lebih sebanyak $2,88 \%$. angka ini menunjukan masih tingginya persentasi anak dibawah dua tahun mengalami masalah gizi dikabupaten kuantan singingi. Status gizi TB/U pada Anak Umur 0-23 Bulan (Baduta) Riskesdas 2018 Provinsi Riau anak sangat pendek di Kabupaten Kuantan Singingi mencapai angka 6,81\% dan Pendek 17,07\%. angka ini menunjukan masih tingginya resiko terjadinya Stunting pada bayi/anak yang ada di kabupaten Kuantan Singingi.

\section{TINJAUAN PUSTAKA}

\subsection{Makanan Pendamping ASI (MPASI)}

Makanan Pendamping Air Susu Ibu (MP-ASI) adalah makanan atau minuman yang mengandung zat gizi yang diberikan pada bayi atau anak usia 6-24 bulan guna memenuhi kebutuhan gizi selain ASI. MP-ASI merupakan makanan peralihan dari ASI ke makanan keluarga. Pengenalan dan pemberian MP-ASI harus dilakukan secara bertahap baik bentuk maupun jumlahnya, sesuai dengan kemampuan bayi. Selama kurun waktu 4-6 bulan pertama ASI masih mampu memberikan kebutuhan gizi bayi, setelah 6 bulan produksi ASI menurun sehingga kebutuhan gizi tidak lagi dipenuhi dari ASI saja. Peranan makanan tambahan menjadi sangat penting untuk memenuhi kebutuhan gizi bayi tersebut (Winarno. 1987, dalam Mufida, dkk. 2015).

\subsection{Gizi Seimbang}

Susunan pangan sehari-hari yang mengandung zat gizi dalam jenis dan jumlah yang sesuai dengan kebutuhan tubuh, dengan memperhatikan prinsip keanekaragaman pangan, aktivitas fisik, perilaku hidup bersih dan memantau berat badan secara teratur dalam rangka mempertahankan berat badan normal untuk mencegah masalah gizi. (Peraturan Menteri Kesehatan Republik Indonesia Nomor 41 Tahun 2014)

\subsection{Gizi Buruk dan Stunting}

Stunting (kerdil) adalah kondisi dimana balita memiliki panjang atau tinggi badan yang kurang jika dibandingkan dengan umur. Kondisi ini diukur dengan panjang atau tinggi badan yang lebih dari minus dua standar deviasi median standar pertumbuhan anak dari WHO. Balita stunting termasuk masalah gizi kronik yang disebabkan oleh banyak faktor seperti kondisi sosial ekonomi, gizi ibu saat hamil, kesakitan pada bayi, dan kurangnya asupan gizi pada bayi. Balita stunting di masa yang akan datang akan mengalami kesulitan 
dalam mencapai perkembangan fisik dan kognitif yang optimal. (Buletin Jendela Data dan Informasi Kesehatan edisi tahun 2018)

\section{METODE PENELITIAN}

\subsection{Menganalisa Masalah}

Langkah menganalisa masalah adalah langkah untuk dapat memahami masalah yang telah ditentukan dalam ruang lingkup atau batasannya. Dengan menganalisa masalah yang ditentukan tersebut, maka masalah dapat dipahami dengan baik. Masalah yang timbul sekarang adalah bagaimana memodelkan aplikasi penunjang keputusan pemberian MPASI dalam mencapai tujuan pemberian nutrisi yang optimal terhadap anak.

\subsection{Pengumpulkan Data}

Dalam pengumpulan data dan informasi, pada tahap ini dilakukan untuk mengetahui mengenai sistem yang diteliti. Dari data dan informasi yang dikumpulan akan didapat data untuk pendukung penelitian. Metode yang digunakan penulis untuk pengumpulan data dengan berbagai metode sebagai berikut:

a. Observasi

Melakukan pengamatan langsung di tempat penelitian untuk mengetahui secara jelas dan terinci permasalahan yang ada. Pengamatan langsung dilalukan pada Dinas kesehatan Kab. Kuantan Singingi.

b. Interview

Dilakukan untuk memperoleh informasi atau data yang dibutuhkan dengan cara melakukan wawancara langsung pada bagian yang terkait yaitu pada Dinas Kesehatan, Orang tua, bidan dan anak.

c. Studi Literatur

Dalam metode ini informasi dikumpulkan dengan membaca jurnal dan buku buku yang berhubungan dengan penelitian untuk menunjang dalam melakukan analisa terhadap data dan informasi. Di antara buku yang berkaitan dengan stunting, MPASI dan jurnal yang berkaitan dengan penelitian.

\subsection{Memodelkan}

Tahap memodelkan rancangan aplikasi ini sangat perlu dilakukan karena model ini nantinya yang akan membantu proses pemograman aplikasi sehingga sesuai dengan kebutuhan yang diinginkan.

\subsection{Pengujian Aplikasi}

Tahap ini digunakan untuk menguji aplikasi yang telah dirancang berdasarkan model yang telah dibuat. Tahap pengujian ini nantinya akan langsung menguji aplikasi kepada responden untuk mengetahui seberapa layak aplikasi ini dalam membantu orang tua untuk mengambil keputusan pemberian makanan pendamping air susu ibu (MPASI) kepada anak.

\subsection{Hasil}

Pada tahap ini akan menampilkan hasil dari proses penelitian ini mulai dari data yang dikumpulkan, dianalisa, model sistem dan hasil dari para responden yang menilai kelayakan aplikasi pendukung keputusan makanan pendamping air susu ibu (MPASI). 


\section{HASIL DAN PEMBAHASAN}

\subsection{Analisis Kebutuhan}

Tahapan ini kegiatan penelitian yang dilakukan adalah mendefinisikan kebutuhan sebelum model dari aplikasi dibuat. Berdasarkan analisis penulis, penulis telah membuat beberapa variabel yang dibutuhkan dalam perancangan aplikasi yaitu Analisis kebutuhan pengguna berdasarkan data dan fakta yang ditemukan dari Dinas Kesehatan dan para orang tua anak baduta, analisis kebutuhan Sistem dan Analisis Kebutuhan Faktor Pendukung System. Berikut ini dijabarkan tiap-tiap kebutuhan yang diperlukan :

\subsubsection{Analisis Kebutuhan Pengguna}

Berdasarkan data yang diambil di dinas Kesehatan kab. Kuantan Singingi ditemukan bahwa masih tingginya angka anak mengalami gizi buruk dan stunting hal ini disebabkan oleh beberapa faktor salah satunya adalah kurang tepatnya pemberian Makanan Pendamping ASI (MPASI) kepada anak baduta. Dari hasil analisis yang dilakukan maka ditemukan kebutuhan-kebutuhan pengguna sebagai berikut :

1. Aplikasi harus mempermudah para orang tua dalam mengetahui status gizi anak

2. Aplikasi harus mempermudah para orang tua mengambil keputusan makanan pendamping ASI ( MPASI ) yang akan diberikan kepada anak.

\subsubsection{Analisis Kebutuhan Sistem}

A. Kebutuhan Fungsional

Dari analisis kebutuhan pengguna tersebut, maka aplikasi mampu melakukan fungsi sebagai berikut. Aplikasi yang dibagun harus mampu menampikan informasi sesuai yang dibutuhkan

B. Kebutuhan Tidak Fungsional

Kebutuhan tidak fungsional adalah kebutuhan sistem yang tidak berhubungan dengan fungsi dari sistem. Adapun kebutuhan tersebut adalah :

1. Aplikasi yang dibagun berbasis mobile dengan sistem operasi android, hal ini dilakukan untuk mempermudah para pengguna untuk mengoperasikannya

2. Desain aplikasi harus user friendly agar mempermudah pengguna dalam mengakses semua kebutuhannya.

\subsection{Pemodelan}

Pada tahapan ini hal yang dilakukan adalah desain terhadap aplikasi yang akan di buat sesuai dengan analisis yang telah dilakukan sebelumnya. Adapun langkah-langkah yang dilakukan dalam proses pemodelan aplikasi ini menggunakan Unifield Modeling Language (UML) adalah sebagai berikut :

\subsubsection{Use Case Diagram}

Usecase Diagram mendiskripsikan interaksi antara satu atau lebih pemakai sistem dengan sistem itu sendiri. 


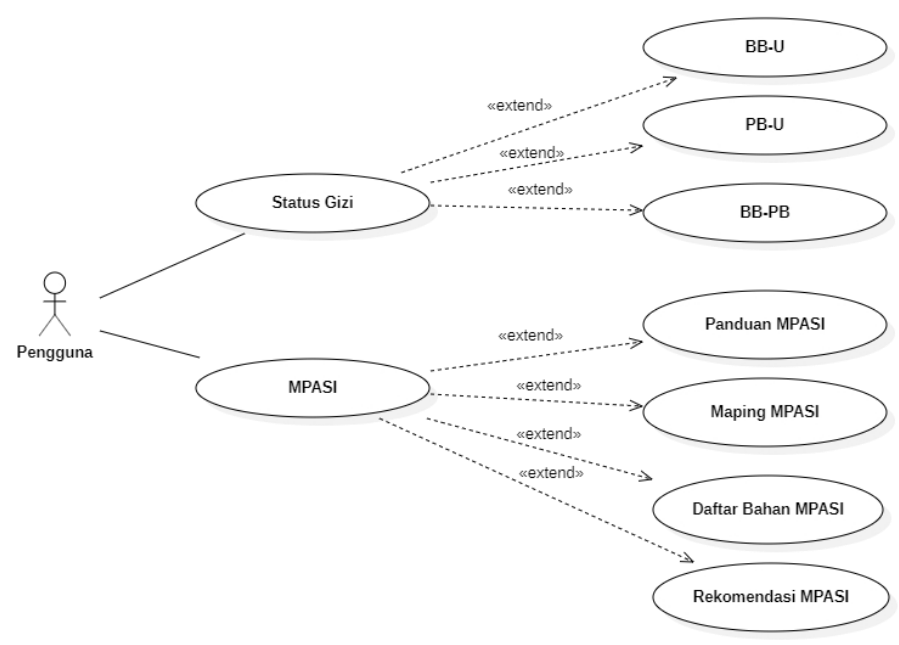

Gambar 4.1 Usecase Diagram

Tabel 4.1 Deskripsi Scenario Usecase

\begin{tabular}{|l|l|}
\hline \multicolumn{1}{|c|}{ Actor } & \multicolumn{1}{|c|}{ Sistem } \\
\hline $\begin{array}{l}\text { Actor sebagai pengguna yang } \\
\text { membuka aplikasi dan memilih } \\
\text { menu yang tersedia }\end{array}$ & Menampilkan menu utama \\
\hline $\begin{array}{l}\text { Pengguna membuka halaman Status } \\
\text { Gizi }\end{array}$ & $\begin{array}{l}\text { Menampilkan Halaman dari Status } \\
\text { Gizi yang extend terhadap BB/U, } \\
\text { PB/U dan BB/PB }\end{array}$ \\
\hline $\begin{array}{l}\text { Pengguna membuka Halaman } \\
\text { MPASI }\end{array}$ & $\begin{array}{l}\text { Menampilkan Halaman MPASI yang } \\
\text { extend terhadap Panduan MPASI, } \\
\text { Maping MPASI, Daftar Bahan } \\
\text { MPASI dan Rekomendasi MPASI }\end{array}$ \\
\hline
\end{tabular}

\subsubsection{Activity Diagram Status Gizi}

Berikut ini merupakan gambar Activity Diagram Status Gizi yang menggambarkan proses terjadinya pada sistem atau interaksi antara Pengguna dengan sistem dalam mengakses halaman Status Gizi :

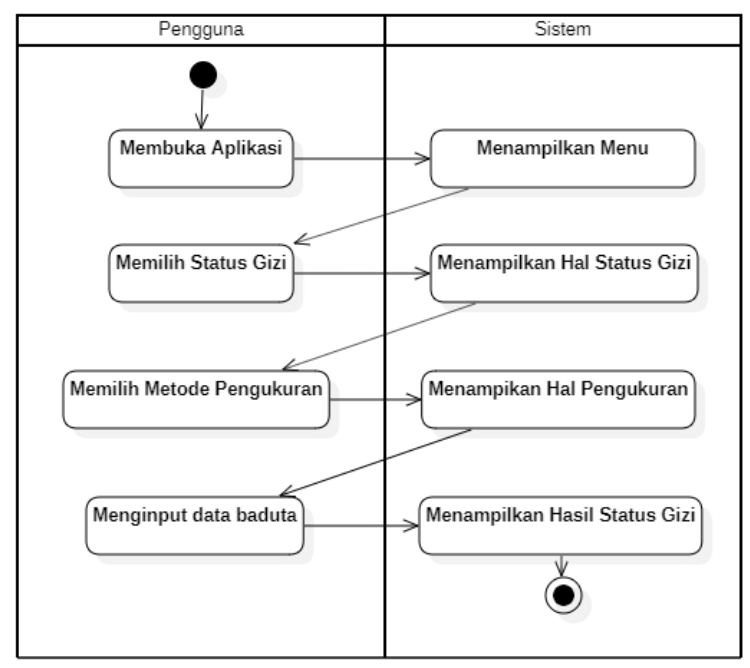

Gambar 2.2 Activity Diagram Status Gizi 


\subsubsection{Activity Diagram MPASI}

Berikut ini merupakan gambar Activity Diagram Makanan Pendamping ASI (MPASI) yang menggambarkan Pengguna dengan sistem dalam mengakses halaman MPASI :

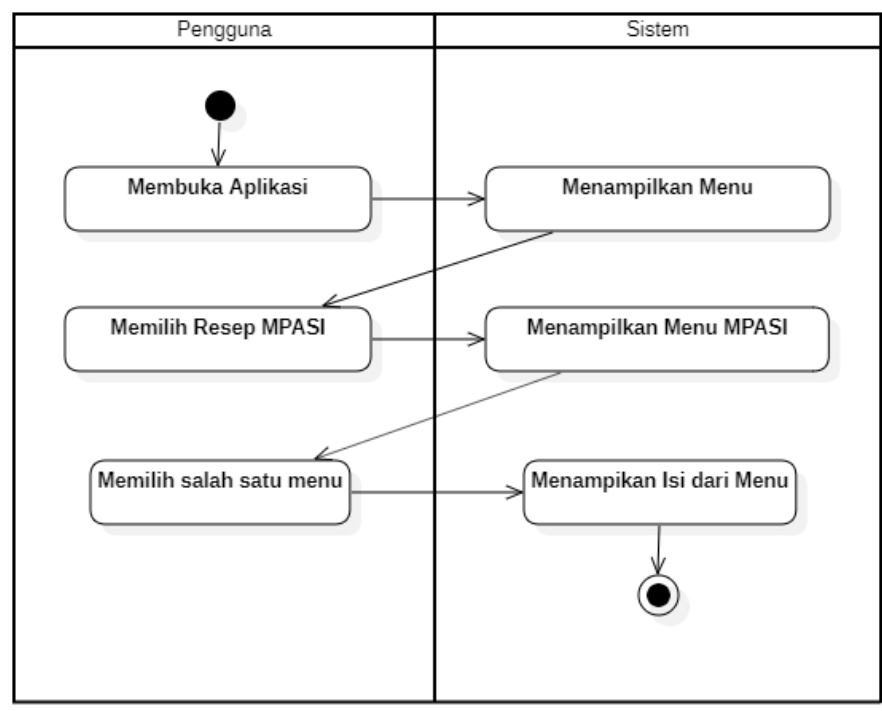

\section{Gambar 4.3 Activity Diagram Kalkulator MPASI}

\subsection{Desain Interface}

Desain Interface menggambarkan bagaimana antarmuka yang akan ditampilkan pada aplikasi untuk mempermudah dalam proses pebuatan aplikasi. Desain interface dapat dilihat sebagai berikut :

\subsubsection{Halaman Menu Utama}

Pada halaman menu utama ini menampilkan apa saja yang bisa diakses oleh pengguna pada saat awal aplikasi dijalankan dimana halaman ini menampikan dua menu yaitu Status Gizi dan MPASI. Berikut gambaran halaman utama :

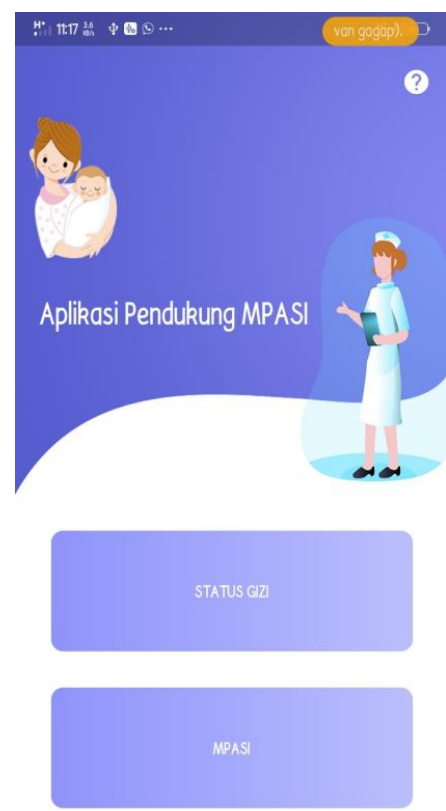

Gambar 4.4 Halaman Menu Utama 


\subsubsection{Halaman Status Gizi}

Berikut ini merupakan gambaran halaman Status Gizi yang digunakan untuk mengukur status gizi bayi dibawah dua tahun (baduta) dengan mengunakan tiga metode yaitu $\mathrm{BB} / \mathrm{U}$, $\mathrm{PB} / \mathrm{U}$ dan $\mathrm{BB} / \mathrm{PB}$ :
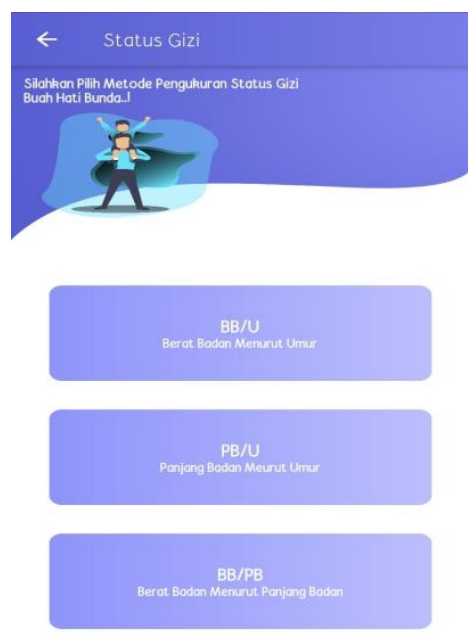

\section{Gambar 4.5 Halaman Menu Status Gizi}

\subsubsection{Halaman Metode BB/U}

Pada halaman ini menggambarkan bagaimana proses pengukuran status gizi anak berdasarkan berat badan terhadap usia :

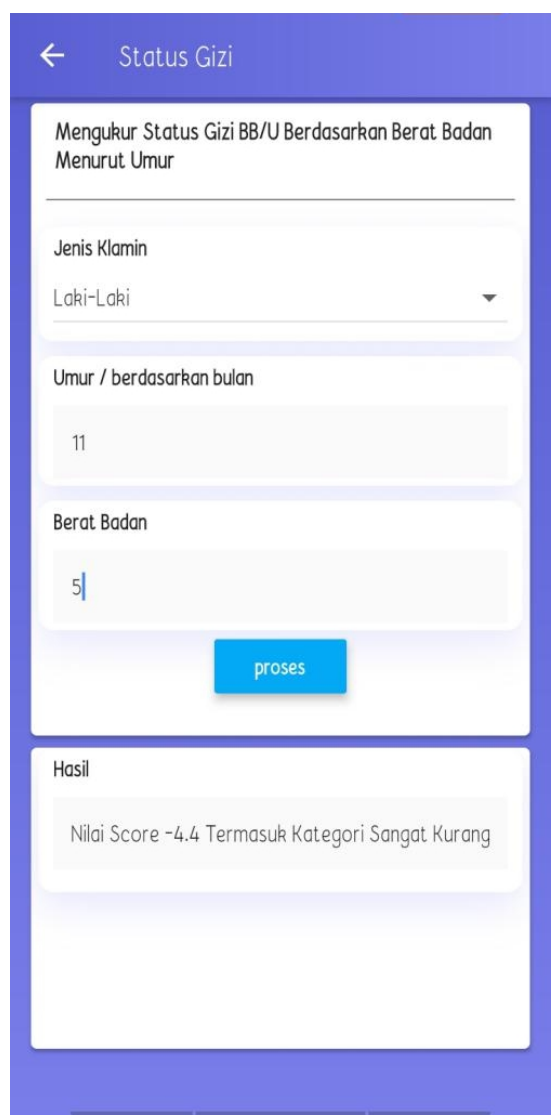

Gambar 4.6 Halaman Metode BB/U 
Hal : $272-283$

\subsubsection{Halaman Metode PB/U}

Pada halaman ini menggambarkan bagaimana proses pengukuran status gizi anak berdasarkan panjang badan terhadap usia :

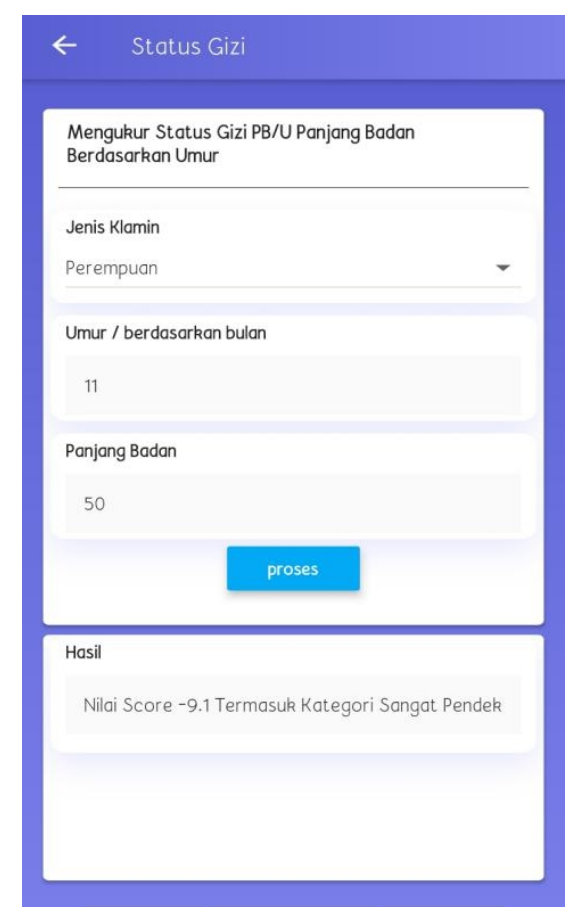

\section{Gambar 4.6 Halaman Metode PB/U}

\subsubsection{Halaman Metode BB/PB}

Pada halaman ini menggambarkan bagaimana proses pengukuran status gizi anak berdasarkan berat badan terhadap panjang badan :

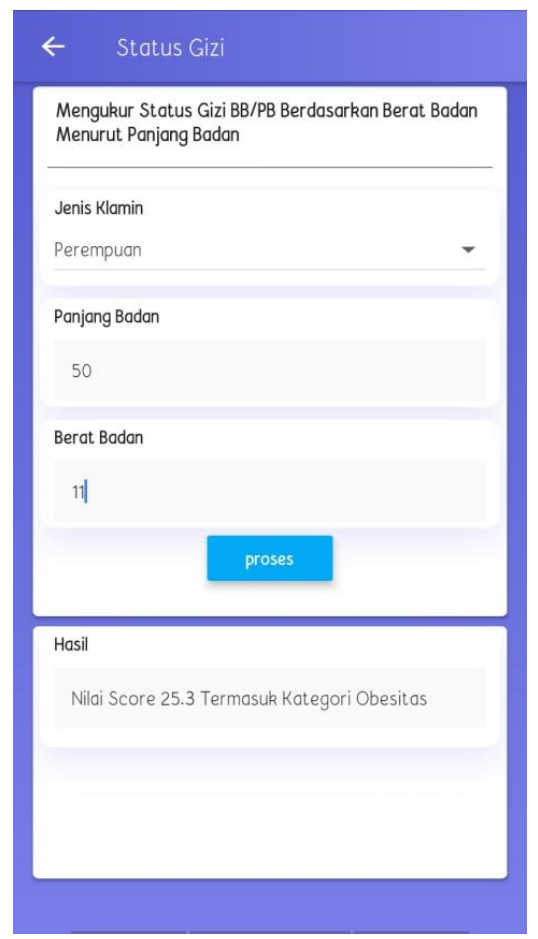

Gambar 4.7 Halaman Metode BB/PB 


\subsubsection{Halaman Menu MPASI}

Pada halaman ini menggambarkan menu MPASI untuk dapat mengakses halaman panduan MPASI, Maping MPASI, Daftar bahan MPASI dan Rekomendasi MPASI :

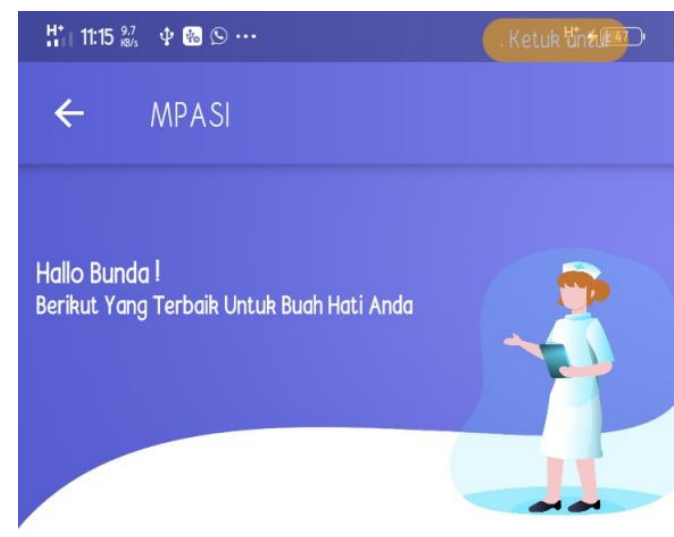

Panduan MPASI

Memandu Strategi Pembarian MPASI

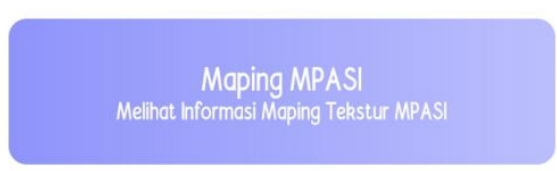

Daftar Bahan MPASI

Melihat Kandungan Gizi Bahan Makanan

Rekomendasi MPASI

Resep MPASI sesuai kebutuhon

\section{Gambar 4.8 Halaman Menu MPASI}

\subsubsection{Halaman Panduan MPASI}

Pada halaman ini menggambarkan halaman Panduan MPASI yang akan menampikan secara detail tahapan-tahapan Makanan Pendamping ASI (MPASI) : 


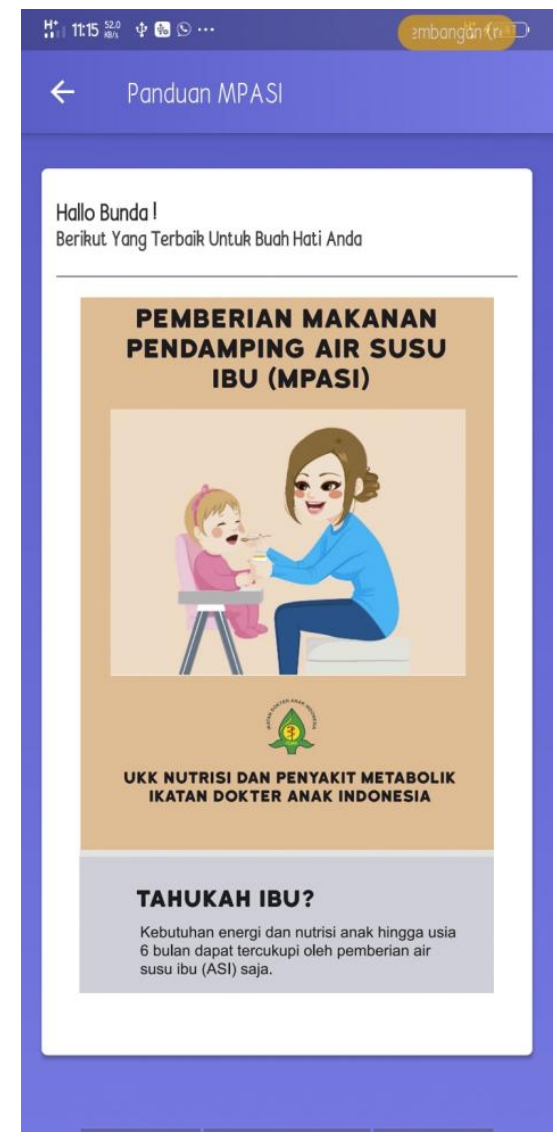

Gambar 4.8 Halaman Panduan MPASI

\subsubsection{Halaman Maping MPASI}

Pada halaman ini menggambarkan halaman Maping MPASI yang akan menampilkan maping untuk tekstur makanan pendamping ASI (MPASI) :

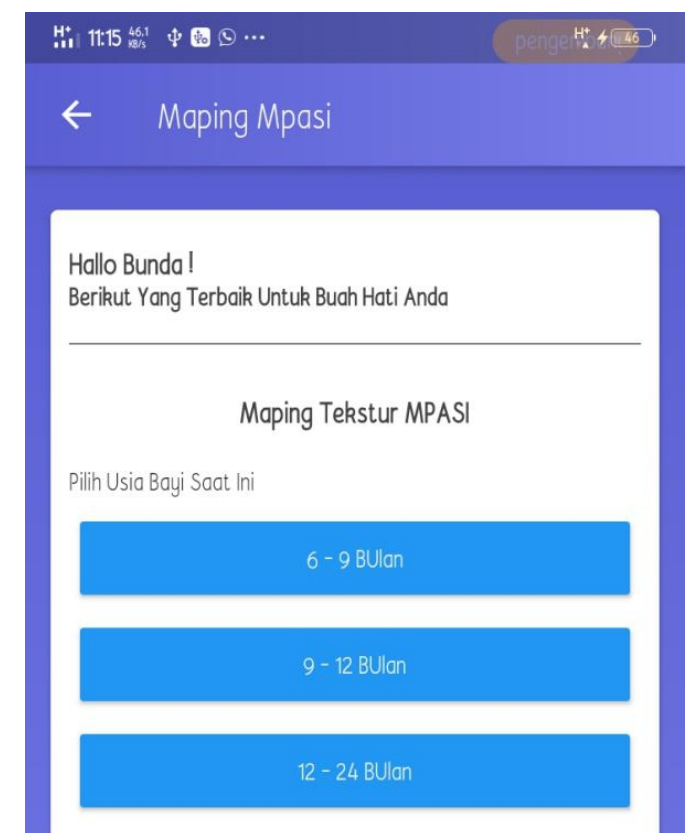

Gambar 4.9 Halaman Maping MPASI 
Hal : 272 - 283

\subsubsection{Halaman Daftar Bahan MPASI}

Pada halaman ini menggambarkan halaman daftar bahan MPASI yang akan menampikan informasi daftar bahan beserta nutrisi dari bahan tersebut :

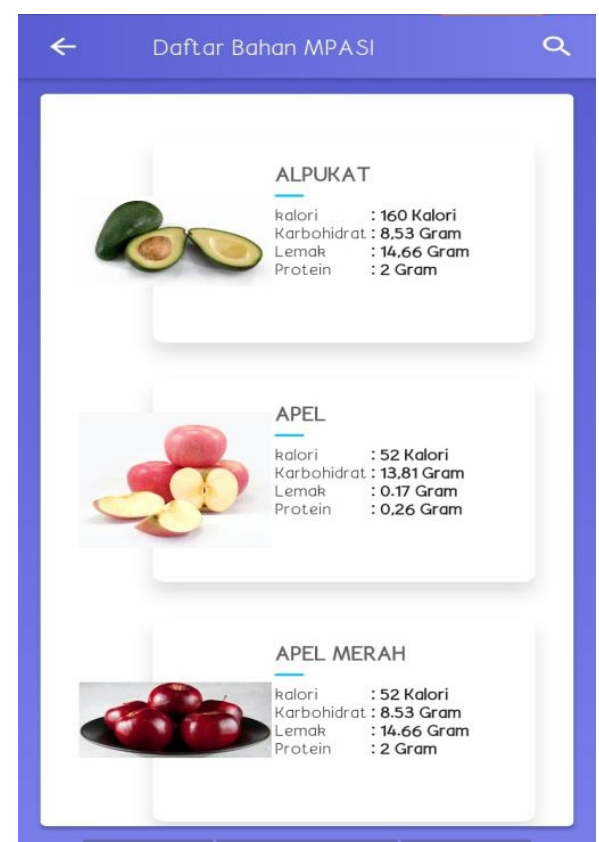

Gambar 4.8 Halaman Daftar Bahan MPASI

\subsubsection{Halaman Rekomendasi MPASI}

Pada halaman ini menggambarkan halaman Rekomendasi MPASI yang akan menampilkan rekomendasi MPASI berdasarkan usia bayi :

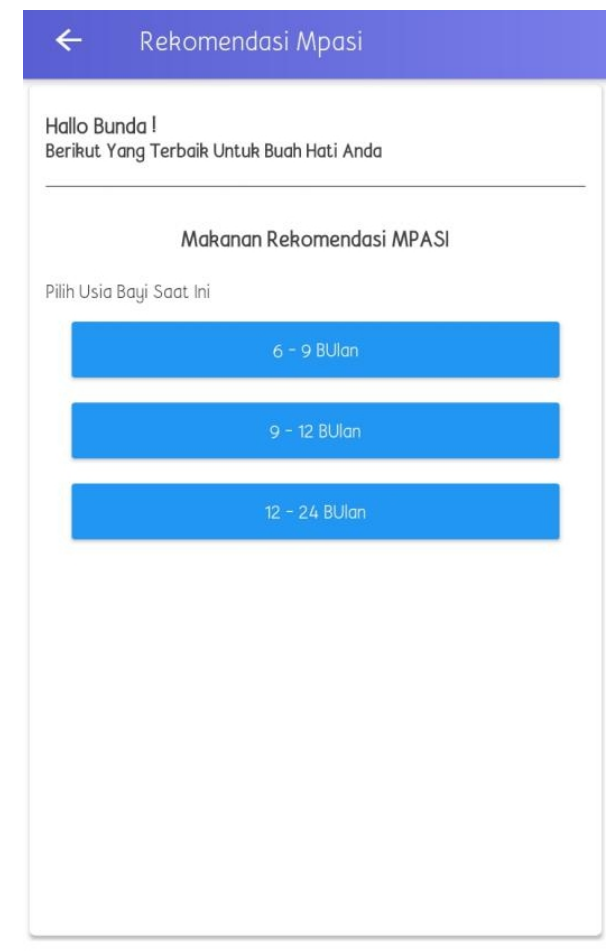




\section{SIMPULAN}

Berdasarkan penelitian yang telah dilakukan maka dapat disimpulkan hasil penelitian ini adalah :

1. Model Aplikasi Makanan Pendamping ASI (MPASI) ini dapat membantu dan mempermudah orang tua dalam memantau tumbuh kembang anak baduta.

2. Aplikasi ini dapat membantu meminimalisir kemungkinan-kemungkinan yang terjadi didalam proses perkembangan anak baduta dan menjadi rujukan orang tua anak.

\section{UCAPAN TERIMAKASIH}

Alhamdulillah, puji syukur selalu peneliti hantarkan kepada Allah SWT yang telah menganugerahkan rahmat, taufik dan berkah-Nya sehingga peneliti dapat menyelesaikan dengan baik. Peneliti juga ingin menyampaikan ucapan terimakasih yang tak terhingga dan penghargaan setinggi-tingginya kepada Civitas Akademika Universitas Islam Kuantan Singingi.

\section{DAFTAR PUSTAKA}

1. Agostoni, C. et al., 2008. Breast-feeding: A commentary by the ESPGHAN Committee on Nutrition. Journal of pediatric gastroenterology and nutrition, 46(1), p.100.

2. Kemenkes RI (2018) Situasi balita Pendek (Stunting) di Indonesia, Buletin jendela Data dan Informasi Kesehatan. ISSN : 2088-270X.

3. Kemenkes RI (2018) Laporan Provinsi Riau Riskesdas, Lembaga Penerbit Badan Penelitian dan Pengembangan Kesehatan (LPB).

4. Badan Pusat Statistik (2020) Kabupaten Kuantan Singingi dalam Angka, BPS Kabupaten Kuantan Singingi/ BPS-Statistics of Kuantan Singingi Regency.

5. Mufida, dkk . (2015). Prinsip Dasar MPASI Untuk Bayi Usia 6-24 Bulan. Jurnal Pangan dan Agroindustri Vol. 3 No 4 p.1646-1651.

6. Permenkes RI (2014) Peraturan Menteri Kesehatan Tentang Pedoman Gizi Seimbang, NOMOR 41 TAHUN 2014.

7. Intje Picauly. (2013). Analisis Determinan Dan Pengaruh Stunting Terhadap Prestasi Belajar Anak Sekolah Di Kupang Dan Sumba Timur, NTT. Jurnal gizi dan pangan,maret 2013, 8(1): 55-62.

8. Rohmani.(2010). Pemberian Makanan Pendamping ASI (MPASI) Pada Anak Usia 1-12 Tahun Di Kelurahan Lamper Tengah Kecamatan Semarang Selatan, Kota Semarang. Jurnal ISBN: 978.979.704.883.9

9. Alter. (2002). Analisis dan Perancangan Sistem Informasi dengan Metodologi Berorientasi Objek, Informatika, Bandung.

10. R Nazli. (2019) Pemodelan Aplikasi Mobile Pelayanan Publik Desa (Smart Village) Berbasis Cloud Computing. Jurnal Teknologi dan Open Source. 2 (2) , 87-95.

11. Turban, E, (2005), Decision Support Systems and Intelligent Systems Edisi Bahasa Indonesia Jilid 1, Andi, Yogyakarta. 